\title{
Pengaruh Inokulan Fungi Mikoriza Arbuskula dan Komposisi Media Tanam pada Pertumbuhan Tanaman Tebu (Saccharum officinarum L.)
}

\author{
Nia Riliana ${ }^{\mathrm{a}}$, Agus Yonathan Parapasan ${ }^{\mathrm{b}}$, Yan Sukmawan ${ }^{\mathrm{b}}$ \\ a Jurusan Budidaya Tanaman Perkebunan, Politeknik Negeri Lampung, Lampung, Indonesia, email: nia24riliana@gmail.com \\ ${ }^{b}$ Jurusan Budidaya Tanaman Perkebunan, Politeknik Negeri Lampung, Lampung, Indonesia, email:ysukmawan@polinela.ac.id
}

\section{Article Info}

Article history:

Received 03 Maret 2020

Received in revised form 25 Mei 2020

Accepted 11 Juli 2020

DOI:

https://doi.org/10.32938/sc.v5i03.1003

Keywords:

Fungi mikoriza arbuskula,

Media tanam,

Tebu

\section{Abstrak}

Pertanaman Tebu di lahan kering dihadapkan pada kurangnya ketersediaan air dan rendahnya kandungan P dalam tanah. Teknologi yang diharapkan mampu memperbaiki produktivitas lahan kering yang ditanami Tebu adalah pengggunaan teknologi mikroba, seperti fung mikoriza arbuskular (FMA) yang disinergikan dengan media tanam kompos sebagai campuran tanah. Penelitian ini bertujuan untuk mendapatkan dosis optimum inokulan FMA, mendapatkan komposisi media tanam terbaik, dan mendapatkan interaksi antara dosis inokulan FMA pada pertumbuhan tanaman Tebu. Penelitian dilaksanakan di Kebun Percobaan Politeknik Negeri Lampung sejak November 2017 sampai Juni 2018. Percobaan menggunakan Rancangan Acak Kelompok berpola faktorial dengan tiga ulangan. Faktor pertama yaitu dosis inokulan FMA yang terdiri atas empat taraf $\left(0\right.$ g.ember ${ }^{-1}, 5$ g.ember ${ }^{-1}, 10$ g.ember ${ }^{-1}$, dan 15 g.ember $\left.{ }^{-1}\right)$; sedangkan faktor kedua yaitu komposisi media tanam kompos: subsoil yang terdiri atas empat taraf $(0 \%: 100 \%, 25 \%: 75 \%, 50 \%: 50 \%$, dan 75

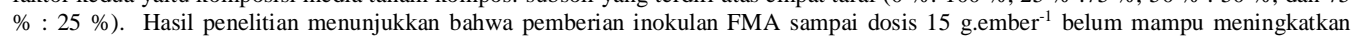
pertumbuhan tanaman Tebu. Komposisi media tanam $25 \%$ kompos : $75 \%$ subsoil sudah mampu meningkatkan jumlah anakan, jumlah daun dan diameter batang tanaman Tebu. Tidak terdapat interaksi antara dosis inokulan FMA dan komposisi media tanam pada pertumbuhan tanaman tebu. Tanaman tebu memerlukan kondisi tanah yang subur, cukup air, dan tidal tergenang.

\section{Pendahuluan}

Tanaman Tebu (Saccharum officinarum L.) dimanfaatkan sebagai bahan baku utama dalam industri gula. Bagian lainnya pada tanaman Tebu dapat dimanfaatkan dalam industri Jamur dan sebagai hijauan pakan ternak, industri pangan, industri non pangan dan industri lain yang menggunakan bahan dari hasil industri gula (Pulungan, 2013; Saptana dan Ilham, 2015; Adiguna dan Wahyudi, 2020). Kendala utama dalam perluasan areal tebu pada lahan kering adalah terbatasnya ketersediaan air khususnya di awal musim kemarau yang menjadikan terhambatnya pertumbuhan vegetatif tanaman tebu dan kurangnya ketersediaan hara khususnya kandungan P. Selain hal di atas, permasalahan pengembangan budidaya tebu pada lahan kering adalah kejenuhan Al tinggi, miskin hara, kejenuhan basa rendah, $\mathrm{pH}$ yang rendah, dan kadar bahan organik rendah (Zulkarnainet al, 2013).Usaha peningkatan kualitas lahan kering mutlak diperlukan. Salah satu usaha teknologi yang diharapkan mampu memperbaiki produktivitas lahan kering yang ditanami tebu adalah pengggunaan teknologi mikroba, seperti fungi mikoriza arbuskular (FMA) yang disinergikan dengan media tanam kompos sebagai campuran tanah. Oleh karena itu, dilakukan percobaan dengan tujuan mendapatkan dosis inokulan FMA yang optimum terhadap pertumbuhan tanaman tebu, mendapatkan komposisi media tanam yang terbaik terhadap pertumbuhan tanaman tebu, serta mengetahui interaksi antara dosis FMA dengan komposisi media tanam terhadap pertumbuhan tanaman tebu.

Pemanfaatan FMA pada tebu lahan kering menyebabkan sistem perakaran tebu akan lebih baik, dibandingkan dengan tebu tanpa menggunakan FMA (Leoviniet al., 2014). Hal ini terjadi karena hifa yang dimiliki oleh FMA mampu memperluas permukaan serapan hara dan air (Wardhikaet al., 2015). Kondisi kekeringan menyebabkan peran FMA akan sangat positif dalam meningkatkan kemampuan tanaman untuk menyerap air dan unsur hara penting seperti fosfor dan unsur hara lainnya, seperti $\mathrm{N}, \mathrm{K}, \mathrm{Zn}, \mathrm{Co}, \mathrm{S}$, dan Mo dari dalam tanah (Leovini et al., 2014).

Kompos mengandung banyak bahan organik yang memiliki pori-pori makro dan mikro yang seimbang sehingga sirkulasi udara yang dihasilkan cukup baik serta memiliki daya serap air yang tinggi di dalam tanah (Lubnan, 2013). Selain itu di dalam kompos juga terkandung unsur hara seperti nitrogen dan fosfat dalam bentuk senyawa kompleks argon, protein, dan humat yang sulit diserap tanaman (Elpawatiet al., 2015). Penggunaan kompos memberikan manfaat yaitu menggemburkan tanah, memperbaiki struktur tanah, serta menghemat pemakaian pupuk kimia.Oleh karena itu, untuk memperbaiki produktivitas lahan kering yang ditanami tebu, perlu dilakukan penelitian kombinasi FMA dengan komposisi media tanam.

\section{Metode}

Penelitian dilaksanakan di kebun percobaan Politeknik Negeri Lampung pada bulan November 2017 sampai Juni 2018. Alat yang digunakan adalah cangkul, pisau, golok, timbangan, ember plastik, jangka sorong, penggaris, termometer, roll meter, alat tulis, oven, kamera, gembor, cawan, pipet, pengaduk, petri dish, tabung reaksi, gelas ukur, alat distilasi, labu ukur, saringan, mortar, erlemenyer, $\mathrm{pH}$ meter, gelas piala, hydrometer, tabung sedimentasi, mixer, dan stopwatch. Bahan yang digunakan adalah inokulan FMA, subsoil dan kompos sebagai campuran tanah sebagai bahan perlakuan, serta Urea $(46 \% \mathrm{~N})$, TSP $\left(46 \% \mathrm{P}_{2} \mathrm{O}_{5}\right)$, dan $\mathrm{KCl}\left(50 \% \mathrm{~K}_{2} \mathrm{O}\right)$ sebagai bahan pupuk dasar, air, bibit bagal satu mata, fungisida, furadan, plastik, akuades, label, tissue, $\mathrm{K}_{2} \mathrm{CR}_{2} \mathrm{O}_{7}, \mathrm{H}_{2} \mathrm{SO}_{4}, \mathrm{H}_{3} \mathrm{PO}_{4}$, Indikator feroin, NFAS, Selen, $\mathrm{NaOH}_{4}$, nesler A dan nesler $\mathrm{B}, \mathrm{NaHCO}_{3}, \mathrm{HCl}$, natrium pirofosfat, serta tajuk dan akar tanaman. Percobaan ini menggunakan Rancangan Acak Kelompok berpola faktorial dengan 2 faktor dan tiga ulangan. Faktor pertama adalah dosis inokulan FMA yang terdiri atas 4 taraf, yaitu :0 g.ember ${ }^{-1}\left(M_{0}\right), 5$ g.ember ${ }^{-1}\left(M_{1}\right)$ 10 g.ember-1 $\left(\mathbf{M}_{2}\right)$ dan 15 g.ember-1 $\left(\mathbf{M}_{3}\right)$. Faktor kedua adalah komposisi media tanam yang terdiri atas 4 taraf, yaitu $0 \%$ kompos: $100 \%$ subsoil $\left(\mathrm{K}_{0}\right), 25 \%$ kompos: $75 \%$ sub soil $\left(\mathrm{K}_{1}\right), 50 \%$ kompos : $50 \%$ sub soil $\left(\mathrm{K}_{2}\right)$, dan $75 \%$ kompos : $25 \%$ subsoil $\left(\mathrm{K}_{3}\right)$. Masing-masing faktor dikombinasikan dengan demikian terdapat 16 kombinasi perlakuan dengan tiga kali ulangan sehingga penelitian ini menghasilkan 48 satuan percobaan.

Setiap satuan percobaan terdapat 1 ember plastik yang masing-masing ember ditanami 1 bibit, sehingga seluruh bibit berjumlah 48 batang. Pengamatan pertumbuhan tanaman tebu diamati berdasarkan variabel jumlah anakan, jumlah daun, diameter batang, tinggi batang, bobot basah tajuk, bobot basah akar, bobot kering tajuk, dan bobot kering akar. Adapun variabel pengamatan di laboratorium yaitu $\mathrm{pH}$ dengan metode $\mathrm{pH}$ meter, N-Total dengan metode $\mathrm{K}$ jeldahl, $\mathrm{P}$ total dengan metode $\mathrm{HCl} 25 \%$ dan $\mathrm{P}$ tersedia dengan metode Bray, $\mathrm{K}$ dengan metode $\mathrm{HCl} 25 \%$, C-organik dengan metode Walkley-Black, serta penetapan tekstur tanah dengan metode Hydrometer Boyoucous. Pengolahan data hasil pengamatan dianalisis menggunakan analisis ragam dengan uji $\mathrm{F}$ pada taraf nyata $5 \%$. Apabila terdapat beda nyata maka akan dilanjutkan dengan Uji BNT pada taraf nyata $5 \%$.

\section{Hasil dan Pembahasan}

Sifat Kimia dan Fisika Media Tanam serta Analisis Kompos yang Digunakan

Parameter penunjang pada penelitian untuk menentukan pengaruh pertumbuhan tanaman tebu akibat perlakuan dosis inokulan FMA dan komposisi media tanam adalah sifat fisik, sifat kimia tanah, dan sifat kimia kompos. Hasil analisis yang diamati antara lain: analisis sampel tanah, kompos kotoran sapi, dan tekstur tanah (Tabel 1).

Tabel 1. Sifat Kimia dan Fisika Media Tanam

\begin{tabular}{|c|c|c|}
\hline Parameter & Nilai & Kriteria \\
\hline \multirow{2}{*}{$\begin{array}{l}\mathrm{pH} \\
\mathrm{N} \text { total }(\%)\end{array}$} & 4,45 & Sangat masam \\
\hline & 0,15 & Sangat rendah \\
\hline $\mathrm{P}$ tersedia $\left(\mathrm{mg} 100 \mathrm{~g}^{-1}\right)$ & 0,12 & Sangat rendah \\
\hline $\mathrm{K}$ total $\left(\mathrm{mg} 100 \mathrm{~g}^{-1}\right)$ & 4,58 & Sangat tinggi \\
\hline $\mathrm{C}$ organik $(\%)$ & 1,70 & Rendah \\
\hline Nisbah C/N & 11,3 & Sedang \\
\hline \multicolumn{2}{|l|}{ Tekstur (\%): } & \multirow{4}{*}{ Lempung berpasir } \\
\hline - Pasir & 76,4 & \\
\hline Debu & 11,2 & \\
\hline Liat & 12,4 & \\
\hline
\end{tabular}

Hasil analisis kompos kotoran sapi menunjukkan bahwa kompos memiliki pH 5,82 (masam), kadar N-total kompos 1,31\% (tinggi), kadar P total kompos 3,80\% (tinggi), kadar kalium kompos 1,83\% (tinggi), dan kadar Corganik kompos $17,98 \%$ (sedang) serta Nisbah C/N 13,72 (sedang).

\section{Pengaruh Dosis Inokulan FMA dan Komposisi Media Tanam pada} Pertumbuhan Tanaman Tebu

Hasil pengamatan menunjukkan bahwa pengaruh mandiri perlakuan dosis FMA menunjukkan hasil tidak berbeda nyata, sedangkan perlakuan 
komposisi media tanam berbeda nyata pada jumlah anakan, jumlah daun, dan diameter batang tanaman tebu. Pengaruh mandiri dosis FMA dan komposisi media tanam pada jumlah anakan, jumlah daun, dan diameter batang tanaman tebu tersaji pada (Tabel2). Pada variabel pengamatan tinggi batang, bobot basah tajuk dan akar, serta bobot kering tajuk dan akar menunjukkan bahwa pengaruh mandiri perlakuan dosis FMA dan komposisi media tanam tidak berbeda nyata. Pengaruh mandiri dosis FMA dan komposisi media tanam pada tinggi batang, bobot basah tajuk dan akar serta bobot kering tajuk dan akar tanaman tebu tersaji pada Tabel 3 .

Tabel 2. Pengaruh Mandiri Dosis FMA dan Komposisi Media Tanam pada Jumlah Anakan, Jumlah Daun dan Diameter Batang Tanaman Tebu 20 MST

\begin{tabular}{|c|c|c|c|}
\hline \multirow[b]{2}{*}{ Perlakuan } & \multicolumn{3}{|c|}{ Variabel pengamatan } \\
\hline & $\begin{array}{c}\text { Jumlah Anakan } \\
\text { (buah) }\end{array}$ & $\begin{array}{c}\text { Jumlah Daun } \\
\text { (helai) }\end{array}$ & $\begin{array}{c}\text { Diameter } \\
\text { Batang }(\mathrm{cm})\end{array}$ \\
\hline \multicolumn{4}{|l|}{ Dosis Inokulan FMA } \\
\hline $\mathrm{M}_{0}\left(0\right.$ g.ember $\left.{ }^{-1}\right)$ & $6,75 a$ & $9,08 \mathrm{a}$ & $2,30 \mathrm{a}$ \\
\hline$M_{1}\left(5\right.$ g.ember $\left.{ }^{-1}\right)$ & $6,83 \mathrm{a}$ & 9,17 a & $2,27 \mathrm{a}$ \\
\hline $\mathrm{M}_{2}\left(10 \mathrm{~g}\right.$ ember $\left.{ }^{-1}\right)$ & $6,83 a$ & $9,08 \mathrm{a}$ & $2,33 \mathrm{a}$ \\
\hline$M_{3}\left(15\right.$ g.ember $\left.{ }^{-1}\right)$ & $6,67 \mathrm{a}$ & $7,75 \mathrm{a}$ & $2,26 \mathrm{a}$ \\
\hline BNT $5 \%$ & 1,443 & 1,557 & 0,186 \\
\hline \multicolumn{4}{|l|}{ Komposisi Media Tanam } \\
\hline $\mathrm{K}_{0}(0 \%$ kompos: $100 \%$ subsoil $)$ & $4,00 \mathrm{a}$ & $7,42 \mathrm{a}$ & $2,15 \mathrm{a}$ \\
\hline $\mathrm{K}_{1}(25 \%$ kompos:75\% subsoil) & $7,58 b$ & $8,67 \mathrm{ab}$ & $2,35 b$ \\
\hline $\mathrm{K}_{2}(50 \%$ kompos: $50 \%$ subsoil $)$ & $7,08 \mathrm{~b}$ & $8,92 \mathrm{ab}$ & $2,35 b$ \\
\hline $\mathrm{K}_{3}(75 \%$ kompos: $25 \%$ subsoil $)$ & $8,42 b$ & $10,08 \mathrm{~b}$ & $2,33 \mathrm{ab}$ \\
\hline BNT $5 \%$ & 1,443 & 1,557 & 0,186 \\
\hline
\end{tabular}

Keterangan: Angka-angka yang diikuti oleh huruf yang sama pada kolom yang sama menunjukkan tidak berbeda nyata pada taraf 5\% uji Beda Nyata Terkecil (BNT)

\section{Jumlah Anakan}

Pengaruh dosis mikoriza terhadap jumlah anakan tidak berbeda nyata disebabkan tingginya unsur hara $\mathrm{P}$ yang terkandung di dalam media tanam. Hal ini menyebabkan media tanam masih mempunyai cadangan hara yang cukup guna menunjang pertumbuhan tanaman. Selain itu, unsur fosfor yang diberikan masih dalam bentuk tidak tersedia bagi tanaman sehingga belum dapat diserap akar tanaman. Menurut Pulungan (2013), P dalam kondisi sangat tinggi akan menyebabkan terpenuhinya nutrisi bagi tanaman. Hal ini berakibat kurangnya infeksi FMA pada tanaman tersebut. Fungsi FMA bagi tanaman adalah sebagai pembantu penyerapan hara khususnya fosfor bagi tanaman, tetapi jika kondisi tanah cukup kandungan nutrisinya, maka FMA akan mengurangi infeksinya. Sebaliknya jumlah anakan pada perlakuan kompos berbeda nyata. Hal ini terjadi karena aplikasi kompos pada media tanam mengandung unsur hara nitrogen dan fosfor yang tinggi sehingga menyebabkan jumlah anakan yang dihasilkan lebih banyak. Menurut Putra et al. (2016), kandungan fosfor pada pupuk organik dapat meningkatkan jumlah anakan tanaman tebu sampai dosis optimum tercapai selanjutnya jumlah anakan akan berkurang jika dosis ditingkatkan.

\section{Jumlah Daun}

Perlakuan dosis mikoriza tidak berbeda nyata pada jumlah daun disebabkan tingginya unsur hara $\mathrm{N}$ yang terkandung di dalam media tanam. Hal ini terjadi karena jumlah daun tanaman Tebu dipengaruhi oleh adanya unsur $\mathrm{N}$. Hal ini sama dengan yang dilaporkan (Lakitan, 2012) unsur hara yang paling berpengaruh terhadap pertumbuhan dan perkembangan daun adalah unsur $\mathrm{N}$. Tabel 2 menunjukkan bahwa jumlah daun pada berbagai komposisi media tanam cenderung mengalami peningkatan, walaupun perlakuan $\mathrm{K}_{1}$ dan $\mathrm{K}_{2}$ tidak berbeda nyata, tetapi jumlah daun pada perlakuan kompos $75 \%\left(\mathrm{~K}_{3}\right)$ cenderung lebih banyak yaitu 10,08 helai dibandingkan dengan perlakuan tanpa kompos yaitu 7,42 helai. Hal ini terjadi karena tingginya kandungan unsur hara pada media tanam terutama nitrogen, fosfor, dan kalium. Hara dalam tanah tersebut terangkut dan terserap oleh akar tanaman, sehingga kemampuan tanah dalam mengikat air dan menyerap hara menjadi semakin baik untuk memberikan dukungan bagi pertumbuhan tanaman. Kadar nitrogen yang tinggi pada media tanam berpengaruh pada pertumbuhan vegetatif tanaman, yang dicirikan dengan peningkatan volume sel tanaman yang tercermin pada tinggi dan diameter batang,serta organ tanaman lainnnya berupa daun dan cabang baru (Andri dan Wawan, 2017).

\section{Diameter batang}

Pengaruh berbagai dosis FMA pada diameter batang (Tabel 2) menunjukkan bahwa perlakuan dosis $10 \mathrm{~g}$ FMA $\left(\mathrm{M}_{2}\right)$ memberikan hasil diameter batang cenderung lebih besar yaitu $2,33 \mathrm{~cm}$ dibandingkan dengan perlakuan tanpa dosis FMA $\left(\mathrm{M}_{0}\right)$. Akan tetapi perlakuan dosis 5 g FMA $\left(\mathrm{M}_{1}\right)$ dan 15 g FMA $\left(\mathrm{M}_{3}\right)$ memberikan hasil diameter batang cenderung lebih rendah yaitu 2,27 cm dan 2,26 cm dibandingkan dengan perlakuan tanpa dosis FMA $\left(\mathrm{M}_{0}\right)$ yaitu $2,30 \mathrm{~cm}$. Hal ini diduga tanah yang digunakan dalam percobaan secara alami sudah mengandung mikoriza. Menurut Aliet al.(2017), inokulasi mikoriza yang tidak berpengaruh terhadap penambahan jumlah daun, jumlah ruas, dan jumlah cabang tanaman lada terjadi karena tanah yang digunakan dalam percobaan secara alami mengandung mikoriza atau media tanam yang digunakan untuk pembibitan lada tidak disterilisasi terlebih dahulu sehingga masih terdapat propagul endogenous FMA yang ternyata masih aktif. Hal ini didukung Wahyu et al. (2013) bahwa infeksi jamur pada tanaman yang tidak diberi mikoriza terjadi karena media tanam yang dipakai untuk percobaan tidak disterilisasi terlebih dahulu sehingga masih terdapat propagul endogenous FMA yang masih aktif. Menurut Cahyani (2009) tanaman kedelai menunjukkan pertumbuhan yang lebih rendah pada tanah yang disterilisasikan terlebih dahulu dibandingkan tanah yang tidak disterilisasikan.Tabel 2 menunjukkan bahwa diameter batang pada berbagai komposisi media tanam relatif hampir sama, tetapi diameter batang pada perlakuan kompos $25 \%\left(\mathrm{~K}_{1}\right)$ dan $50 \%\left(\mathrm{~K}_{2}\right)$ cenderung lebih besar yaitu $2,35 \mathrm{~cm}$ dibandingkan dengan perlakuan lainnya. Menurut Elpawati et al. (2015), aplikasi kompos pada media tanam mengandung banyak unsur hara seperti nitrogen dan fosfat dalam bentuk senyawa argon, protein, dan humat yang sulit diserap tanaman. Kemungkinan hal tersebut yang menyebabkan lebih rendahnya diameter batang pada perlakuan kompos $75 \%\left(\mathrm{~K}_{3}\right)$. Sebaliknya, Fatimah dan Handarto (2008) menyatakan bahwa kadar $\mathrm{N}$ (nitrogen) yang tinggi pada media tanam sangat berpengaruh terhadap pertumbuhan vegetatif, yang dicirikan oleh penambahan volume sel tanaman khususnya diameter batang dan organ tanaman lain seperti daun dan cabang baru.

\section{Tinggi batang}

Perlakuan dosis FMA tidak berpengaruh nyata pada tinggi batang tanaman tebu. Hal ini diduga karena perakaran tebu belum berfungsi secara sempurna sehingga peran mikoriza dibagian perakaran membutuhkan waktu relatif lebih lama. Selain itu, kesesuaian jenis mikoriza dengan tanaman inang memberikan kontribusi terhadap lamanya proses penginfeksian perakaran (Putra, 2015). Tabel 3 menunjukkan bahwa perlakuan kompos tidak berbeda nyata pada tinggi batang tanaman tebu. Hal ini terjadi karena $\mathrm{pH}$ tanah percobaan tergolong masam yaitu 4,45. Hal ini sama dengan yang dilaporkan (Adnan, 2014) pemberian SP-36 tidak mempengaruhi tinggi batang pada $\mathrm{pH}$ tanah Ultisol yang rendah (tergolong masam), sehingga sebagian unsur hara $\mathrm{P}$ tidak dapat diserap oleh tanaman karena difiksasi oleh Al dan Fe. Keadaan ini menyebabkan rendahnya unsur hara $\mathrm{P}$ dalam menunjang tinggi batang tanaman. Hal berbeda dilaporkan Audi (2016) yang menyatakan bahwa tinggi batang tanaman jagung dipengaruhi oleh ketersediaan air. Proses yang sensitif terhadap kekurangan air adalah pembelahan sel. Hal ini dapat diartikan bahwa tanaman sangat peka terhadap defisit air karena berhubungan dengan turgor, sehingga hilangnya turgiditas dapat menghentikan pembelahan dan pembesaran sel yang mengakibatkan tanaman menjadi kerdil.

Tabel 3. Pengaruh mandiri dosis FMA dan komposisi media tanam pada tinggi batang, bobot basah tajuk dan akar, serta bobot kering tajuk dan akar tanaman tebu 20 MST

\begin{tabular}{|c|c|c|c|c|c|}
\hline \multirow[b]{2}{*}{ Perlakuan } & \multicolumn{5}{|c|}{ Variabel pengamatan } \\
\hline & $\begin{array}{c}\text { Tinggi } \\
\text { Batang } \\
(\mathrm{cm})\end{array}$ & $\begin{array}{c}\text { Bobot } \\
\text { Basah } \\
\text { Tajuk } \\
(\mathrm{g}) \\
\end{array}$ & $\begin{array}{c}\text { Bobot } \\
\text { Basah } \\
\text { Akar (g) }\end{array}$ & $\begin{array}{c}\text { Bobot } \\
\text { Kering } \\
\text { Tajuk } \\
(\mathrm{g})\end{array}$ & $\begin{array}{c}\text { Bobot } \\
\text { Kering } \\
\text { Akar (g) }\end{array}$ \\
\hline \multicolumn{6}{|l|}{ Dosis Inokulan FMA } \\
\hline $\mathbf{M}_{0}\left(0\right.$ g.ember $\left.{ }^{-1}\right)$ & $80,54 \mathrm{a}$ & $414,94 a$ & $468,75 a$ & $114,05 \mathrm{a}$ & $113,42 a$ \\
\hline$M_{1}\left(5\right.$ g.ember $\left.{ }^{-1}\right)$ & $81,08 \mathrm{a}$ & $397,64 a$ & $488,75 a$ & $120,63 a$ & $116,56 a$ \\
\hline $\mathrm{M}_{2}\left(10\right.$ g.ember $\left.{ }^{-1}\right)$ & $85,04 \mathrm{a}$ & $446,66 a$ & $458,33 a$ & $128,36 \mathrm{a}$ & $118,72 \mathrm{a}$ \\
\hline$M_{3}\left(15\right.$ g.ember $\left.{ }^{-1}\right)$ & $79,40 \mathrm{a}$ & $378,39 a$ & $403,75 \mathrm{a}$ & $117,28 \mathrm{a}$ & $111,26 a$ \\
\hline BNT 5\% & 11,737 & 118,664 & 94,718 & 31,613 & 13,540 \\
\hline
\end{tabular}

Komposisi Media Tanam

$\mathrm{K}_{0}(0 \%$ kompos: $100 \%$ subsoil) $78,38 \mathrm{a} \quad 395,88 \mathrm{a} \quad 403,75 \mathrm{a} \quad 123,26 \mathrm{a} \quad 110,70 \mathrm{a}$

$\mathrm{K}_{1}(25 \%$ kompos:75\% subsoil) 80,21a $420,73 \mathrm{a} \quad 491,67 \mathrm{a} \quad 122,69 \mathrm{a} \quad 119,38 \mathrm{a}$

$\mathrm{K}_{2}(50 \%$ kompos:50\% subsoil) $78,23 \mathrm{a} \quad 380,13 \mathrm{a} \quad 437,92 \mathrm{a} \quad 108,10 \mathrm{a} \quad 116,60 \mathrm{a}$

$\mathrm{K}_{3}$ (75\% kompos:25\% subsoil) 89,25a $440,89 \mathrm{a} \quad 494,72$ a $\quad 126,27 \mathrm{a} 113,28 \mathrm{a}$ $\begin{array}{llllll}\text { BNT 5\% } & 11,737 & 118,664 & 94,718 & 31,613 & 13,540\end{array}$

Keterangan : Angka-angka yang diikuti oleh huruf yang sama pada kolom yang sama menunjukkan tidak berbeda nyata pada taraf $5 \%$ uji Beda Nyata Terkecil (BNT)

\section{Bobot Basah Tajuk dan Bobot Basah Akar}

Bobot basah tajuk dan akar pada berbagai dosis FMA dan komposisi media tanam tidak berbeda nyata. Menurut Fatima dan Handarto (2008) bobot segar tajuk dan akar merupakan hasil pertumbuhan suatu tanaman diperoleh dari pengubahan energi matahari menjadi energi kimia yang dipengaruhi dengan ketersediaan hara dan air di dalam tanah. Kebutuhan air yang tidak tercukupi menyebabkan metabolit untuk kelangsungan hidup tanaman juga menjadi tidak tersedia. Hal ini sama dengan yang dilaporkan Audi (2016) yang menyatakan bahwa transpirasi dan fotosintesis yang rendah terjadi pada kandungan air tanah yang lebih sedikit. Rendahnya kedua aktivitas fisiologis tanaman ini berakibat bagi pertumbuhan tanaman seperti bobot basah tanaman.

\section{Bobot Kering Tajuk dan Bobot Kering Akar}

Perlakuan dosis FMA dan komposisi media tanam tidak berpengaruh nyata pada bobot kering tanaman (tajuk dan akar). Hal ini diduga karena sedikitnya kandungan air pada sampel yang digunakan. Air merupakan salah satu faktor dari proses fotosintesis, jika air yang dibutuhkan tidak tercukupi hingga berakhirnya masa vegetatif, maka proses fotosintesis tidak 
akan berjalan lancar yang mengakibatkan bobot kering tanaman menjadi rendah (Audi, 2016)

\section{Simpulan}

Pemberian dosis inokulan FMA tidak berpengaruh nyata pada jumlah anakan, jumlah daun, diameter batang, tinggi batang, bobot basah tajuk, bobot basah akar, bobot kering tajuk, dan bobot kering akar. Pemberian komposisi media tanam $25 \%$ kompos:75\% sub soil sudah mampu meningkatkan jumlah anakan, jumlah daun, dan diameter batang tanaman tebu. Serta tidak terdapat interaksi antara pemberian dosis inokulan FMA dan komposisi media tanam pada jumlah anakan, jumlah daun, diameter batang, tinggi batang, bobot basah tajuk, bobot basah akar, bobot kering tajuk, dan bobot kering akar.

\section{Pustaka}

Adnan, I. S., Utoyo, B., \& Kusumastuti, A. 2015. Pengaruh pupuk NPK dan pupuk organik terhadap pertumbuhan bibit kelapa sawit (Elaeis guineensis Jacq.) di main nursery. Jurnal Agro Industri Perkebunan, 3(2): 69-81.https://doi.org/10.25181/aip.v3i2.20

Adiguna, A., \& Wahyudi, A. 2020. Pemanfaatan Abu Ampas Tebu Limbah Pabrik Gula Cinta Manis Kabupaten Ogan Ilir Sebagai Additive Beton. Sainmatika: Jurnal Ilmiah Matematika dan Ilmu Pengetahuan Alam, 17(1): 46-54. http://dx.doi.org/10.31851/sainmatika.v17i1.3383

Ali, F., Subechan, M. A., \& Prasetia, B. 2017. Respons Pertumbuhan Lada Perdu terhadap Pemberian Dosis Pupuk Kandang Sapi dan Mikoriza. Jurnal Agro Industri Perkebunan, 5(2): 7988.https://doi.org/10.25181/jaip.v5i2.341

Andri, R. K., \& Wawan. 2017. Pengaruh pemberian beberapa dosis pupuk kompos (greenbotane) terhadap pertumbuhan bibit kelapa sawit (Elaeis quieneensis Jacq.) di pembibitan utama. JOM Faperta 4(2):1-14.

Audi, R. F. 2016. Pengaruh Berbagai Macam Sumber Bahan Organik untuk Meningkatkan Pertumbuhan dan Hasil Tanaman Jagung di Lahan Pasir Pantai Samas. [skripsi] Universitas Muhammadiyah Yogyakarta.

Cahyani, V. R. 2013. Pengaruh beberapa metode sterilisasi tanah terhadap status hara, populasi mikrobiota, potensi infeksi mikorisa dan pertumbuhan tanaman. Sains Tanah-Journal of Soil Science and Agroclimatology, 6(1): 43-52.

Elpawati, Y.K.S, S. D. D. \& Dasumiati. 2015. Optimalisasi Penggunaan Pupuk Kompos dengan Penambahan Effective Microorganism 10 (EM10) pada pada Produktivitas Tanaman Jagung (Zea mays L.). Jurnal Biologi, 8(2): $77-87$.

Fatimah, S. \&Handarto, B. M. 2008. Pengaruh Komposisi Media Tanam terhadap Pertumbuhan dan Hasil Tanaman Sambiloto (Andrographis panicula Nees). Embryo, 5(2): 133-148.

Lakitan, B. 2012. Dasar-Dasar Fisiologi Tumbuhan. Jakarta: PT Raja Granfindo.

Leovini, H., Kastono, D.\& Widada, J. 2014. Pengaruh Pemberian Jamur Mikoriza Arbuskular, Jenis Pupuk Fosfat dan Takaran Kompos terhadap Pertumbuhan Bibit Tebu (Saccharum officinarum L.) pada Media Pasir Pantai. Vegetalika, 3(1): 102-115.

Lubnan, S. D. 2013. Pengaruh Media Tanam Organik terhadap Pertumbuhan dan Perakaran pada Fase Awal Benih Teh di Pembibitan. Jurnal Penelitian Teh dan Kina, 16(1): 1-11.

Pulungan, A. S. S. 2013. Infeksi Fungi Mikoriza Arbuskula pada Akar Tanaman Tebu (Saccharum officinarum L.). Jurnal Biosains Unimed, 1(1): 43-46.

Putra, M. M. 2015. Pengaruh Cendawan Mikoriza Arbuskula dan Fosfat pada Pertumbuhan Tanaman Tebu (saccharum officinarum Linn). [skripsi] Politeknik Negeri Lampung.

Putra, E., Sudirman, A., \& Indrawati, W. 2016. Pengaruh pupuk organik pada pertumbuhan vegetatif tanaman tebu (Saccharum officinarum L.) Varietas GMP 2 dan GMP 3. Jurnal Agro Industri Perkebunan, 4(2): 6068. https://doi.org/10.25181/aip.v4i2.44

Saptana dan Ilham, N. 2015. Pengembangan sistem integrasi tanaman tebu-sapi potong di Jawa Timur. Analisis Kebijakan Pertanian, 13(2): 147-165. http://dx.doi.org/10.21082/akp.v13n2.2015.147-165

Wardhika, C. M., Hadisutrisno, B.\& Widada, J. 2015. Potensi Jamur Mikoriza Arbuskular Unggul dalam Peningkatan Pertumbuhan dan Kesehatan Bibit Tebu (Saccharum officinarum L.). Jurnal Ilmu Pertanian, 18(2): 84-91.

Zulkarnain, M., Prasetya, B.\& Soemarno. 2013. Pengaruh Kompos, Pupuk Kandang, dan Custom-Bio terhadap Sifat Tanah, Pertumbuhan dan Hasil Tebu (Saccharum officinarum L.) pada Entisol di kebun Ngrakah-Pawon, Kediri. Indonesian Green Technology Journal, 2(1): 45-52.

Wahyu, E. R., Purwani, K. I., \& Nurhatika, S. 2013. Pengaruh Glomus fasciculatum pada pertumbuhan vegetatif kedelai yang terinfeksi Sclerotium rolfsii. Jurnal Sains dan Seni ITS, 2(2): E64-E68. 